\title{
植物の乾燥ストレス耐性を付与する分子の開発”
}

\author{
岡本昌憲* \\ 宇都宮大学・バイオサイエンス教育研究センター
}

（2021年5月 10 日受理）

\section{Development of small molecules that improve drought stress tolerance in plants}

\author{
Masanori Окамото \\ Center for Bioscience Research and Education, Utsunomiya University, 350 Mine-cho, Utsunomiya, Tochigi, 321-8505, Japan
}

Keywords: abscisic acid, plant hormones, receptor, agonist, drought.

\section{は じめに}

近年の気候変動により, 環境ストレスによる農作物の被害 が増えている.ゲノム編集や遺伝子情報を活用した分子育種 によって, 環境ストレスに耐性をもち, 安定的な食糧生産が 可能な作物開発が急ピッチで進められている. 筆者の研究グ ループも, 耐乾性と節水性を兼水備えたコムギを遺伝子組 換え技術で開発したが, 形質転換体の作成から閉鎖系実験 室での形質評価に至るまで, 実験開始から 7 年もの歳月を要 した. ${ }^{1)}$ そして, 野外の乾燥地で而乾性を評価し, その効果 を検証するにはさらなる時間を要する。 つまり, 分子育種技 術が発展した現代においても, 作物改良には一定の時間を要 し, 植物種ごとに分子育種を適用して多様な植物や作物を改 良していくには, 多大な労力を要する.したがって, 分子育 種とは異なる技術も組み合わせ，作物の環境ストレスに対す る適応能力を改善することが今後の農業に重要であると思わ れる．植物の環境ストレスで世界的に大きな問題となってい るものは, 地球温暖化に伴う乾燥ストレスと熱ストレスであ る.両者のストレスを同時に克服できることが望ましいが,

\footnotetext{
\#第46回大会シンポジウムを取りまとめた解説.

* ₹ 321-8505 栃木県宇都宮市峰町 350

E-mail: okamo@cc.utsunomiya-u.ac.jp

(C) 日本農薬学会
}

ここでは植物の乾燥ストレスについて言及したい. 植物の乾燥ストレス耐性には, 植物ホルモンのアブシシ ン酸（abscisic acid: ABA）が必須であることが知られてい る. ABAは陸上植物に普遍的に存在し, 植物が乾燥ストレ スを受けると内生 $\mathrm{ABA}$ 量が増加し, 気孔閉鎖や細胞がスト レス障害から防御するための様々な遺伝子の発現誘導や適合 溶質の蓄積をもたらす。 $\mathrm{ABA}$ はこのような生理作用を発揮 することから, 植物成長調節剂として農業に広く利用されて もよいように思われるが, 実際は, オーキシンやジベレリン などのほかの植物ホルモンに比べ，利用の普及がなされてい ない. その理由として, ABAの価格の問題, 投資に見合っ た利益・有益性がもたらされるのか不明である点など複合 的な問題があるように思われる。一方で，ABAを生産する カビの発酵技術を利用して, ABA を配合した肥料が販売さ れ, ミヨビ農法として様々な植物において ABAの効果が認 められている. 野外におけるABAの効果は, 環境の安定し た実験室内で見られる効果とは大きく異なり, 植物の成長促 進, 果実の肥大や成熟促進, 耐病性獲得など農業上有益な効 果が認められる. ${ }^{2)}$ また, ABAは果実や種子に大量に含まれ ていることが多く, 人体には毒性がない. そのため, ミヨビ 農法は安全性の高い方法であるが，ABAは強光によりその 半分は活性のない異性体へ平衡的に変化し, さらには酸化や 土㙴細菌・微生物などによる加水分解のほか, 植物体内では $\mathrm{ABA}$ 代謝酵素によって不活性化されるなど不安定な化学特 
性を有している，農業市場で広く利用されている植物ホルモ ンに関連した植物成長調節剂の多くは，天然の植物ホルモン とは異なる化学構造を有している。このことからも，ABA の特性を広く活用するためにも, ABA と同様の作用を示す アゴニストの開発や利用も必要と思われる。そこで，ここで は，これまで筆者が関わってきた ABAアゴニストの開発を 中心に解説したい.

\section{1. アブシシン酸のシグナル伝達}

$\mathrm{ABA}$ アゴニストの開発に先立ち, ABAがどのように受 容され，シグナルを伝えるのかを説明する，ABA は受容体
によって認識されたのち, 様々なシグナル伝達因子を介し て ABAの生理作用をもたらす (図 1). ${ }^{3)} \mathrm{ABA}$ を受容する受 容体は, START (Steroidogenic acute regulatory proteinrelated lipid transfer）ドメイン・スーパーファミリーに属す るタンパク質である。シロイヌナズナにはABA受容体であ る PYR/PYLタンパク質が14の遺伝子によってコードされ, 進化的にタイプ1から 3 の三種類に分類される. ${ }^{4 ）}$ シロイヌ ナズナのタイプ1（PYL7-10）は, ゼニゴケから出現し，つ いで維管束系発達の過程でタイプ2（PYL4-6, PYL11-13） が出現し,これらは生化学的に単量体でABAに対して高親 和性である. 5) 対して, タイプ3（PYR, PYL1-3）は被子植

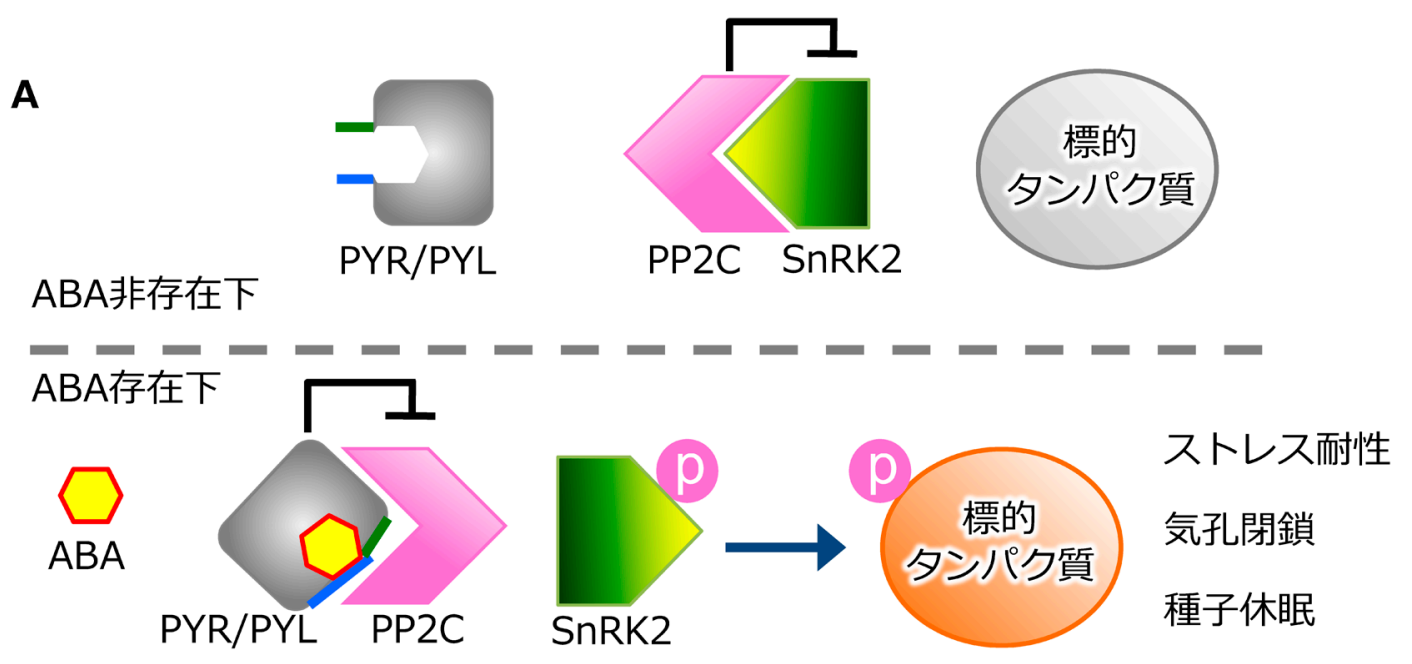

B
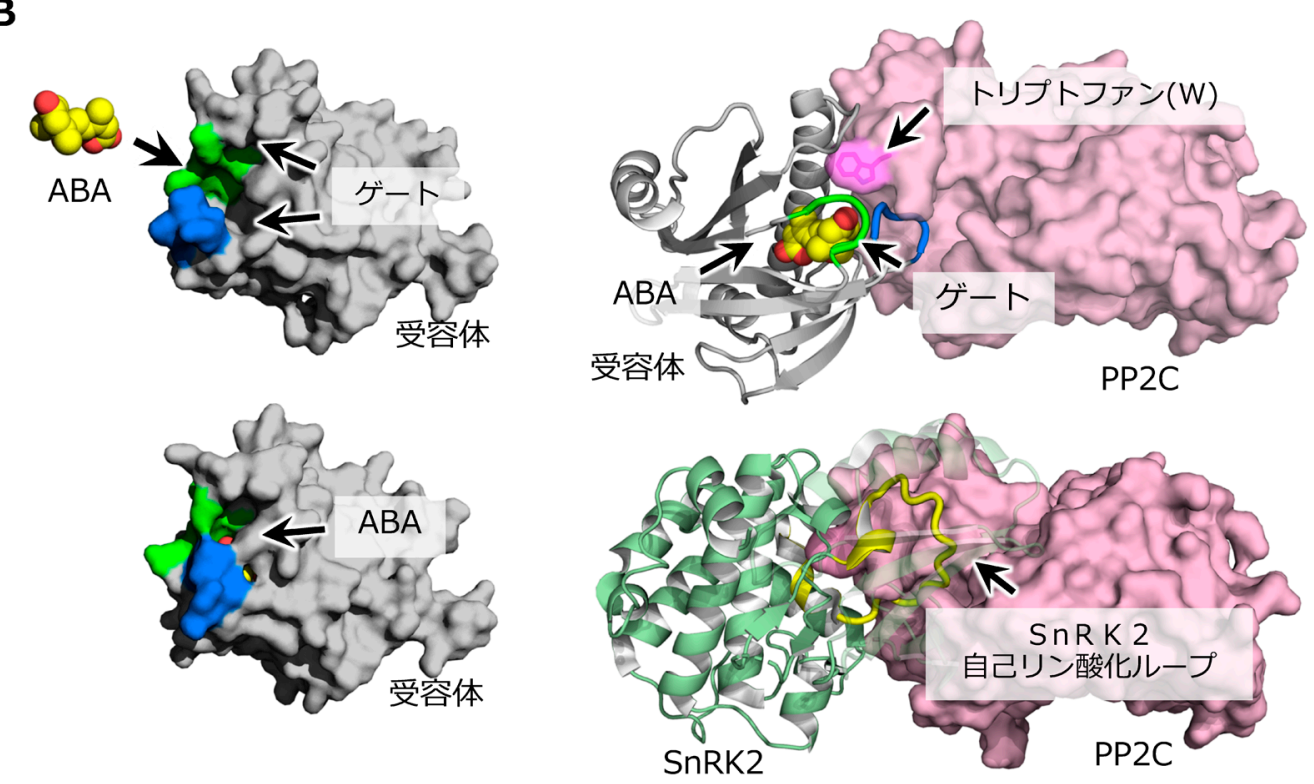

図 1.（A）高等植物における $\mathrm{ABA}$ シグナル伝達経路.（B）結晶構造解析から明らかになった $\mathrm{ABA}$ 受容体による PP2Cの阻害，PP2Cによる SnRK2の阻害様式. ABA が受容する前の受容体はゲートが開いており，リガンド結合ポケットが見える（左上）。ABAを受容すると受容体 のゲートが閉じて ABA を包み込み（左下），ゲート部分がPP2C の活性部位に蓋をするように結合して，PP2Cの活性を阻害する（右上）。ま た， $\mathrm{PP} 2 \mathrm{C}$ のリプトファン残基は $\mathrm{ABA}$ と ABA受容体のゲート部分と強固な水分子を介した水素結合ネットワークにより，受容体と $\mathrm{PP} 2 \mathrm{C}$ の結合に鍵をかける．PP2CがSnRK2の自己リン酸化ループを挟み込み, SnRK2 の活性を阻害する様子（右下）. 
物に広く保存され，二量体型で低親和性の性質を有してい る. ABAがPYR/PYL受容体のリガンド結合ポケットに入 り込むと, 受容体のポケット入り口の2つのループを閉じ てABAを包み込む（図 1). ABA を包み込んだ受容体複合体 は, $\mathrm{ABA}$ シグナル伝達系における負の制御タンパク質であ るタンパク質脱リン酸化酵素 $2 \mathrm{C}(\mathrm{PP} 2 \mathrm{C})$ と結合し, ABA受 容体のループが PP2Cの活性部位をブロックするように挿入 されることで, PP2Cの活性を $\mathrm{ABA}$ 依存的に阻害する. タン パク質リン酸化酵素である（SnRK2）は，ABAが存在しな い状態では，PP2Cによって活性が阻害されているが， ABA 存在下では ABA受容体によって PP2Cの活性が阻害される ために, SnRK2 はPP2Cの制御から解放される（図1)。この ような状態において, SnRK2の自己リン酸化によりリン酸 化活性が回復する。活性化したSnRK2 は様々な標的タンパ ク質をリン酸化することで, ABAの生理作用を引き起こす. SnRK2によるリン酸化を受けた陰イオンチャネル（SLAC1） は塩化物イオン $\left(\mathrm{Cl}^{-}\right)$を細胞外へ排出するように機能し, 一方で, SnRK2によるリン酸化を受けたカリウムチャネル （KAT1）は機能が阻害され，細胞内にカリウムイオン $\left(\mathrm{K}^{+}\right)$ の流入を阻害する.SnRK2がこれらの2つのチャネルの機 能を制御することで，孔辺細胞内の膨圧を低下させ，効率 良く気孔を閉鎖させる。そのほか，ABAは乾燥ストレス時 における細胞のダメージを軽減・保護させるために，プロリ ンや糖などの適合溶質の蓄積, late embryogenesis abundant
（LEA）タンパク質やヒートショックタンパク質 (HSP) の 誘導を引き起こす。これらの遺伝子のプロモーター領域には bZIP型転写因子が結合するシス配列が存在し, SnRK2によ り bZIP型転写因子がリン酸化されることで, 標的遺伝子の 発現誘導を引き起こし, 植物のストレス耐性を付与する.つ まり, $\mathrm{ABA}$ シグナルの全体像が見えてくると, $\mathrm{ABA}$ の生理 作用が引き起こされるためには, 受容体と標的タンパク質の $\mathrm{PP} 2 \mathrm{C}$ が ABA依存的に結合しなければならないことが理解 できる。

\section{2. ケミカルスクリーニングによる ABA アゴニストの探索と構造展開}

$\mathrm{ABA}$ 受容体が発見されたのち, ABAアゴニストの探索や 開発が加速した。 $\mathrm{ABA}$ 受容体の発見の立役者となったピラ バクチンは種子発芽阻害をもたらすABAアゴニストとして ケミカルスクリニーニングによって単離されたが, 植物体の 乾燥ストレス応答を誘導する事は出来なかった. ${ }^{6)}$ ま, ピ ラバクチンの発見後に，アナログが開発されたたものの，い ずれも強い活性を示すものは見出されなかった。この理由 は，ピラバクチンがPYR1 やPYL1受容体にはアゴニストで あるのに対して, PYL2受容体にはアンタゴニストとして作 用してしまうことや，それらのアナログにはABAのシクロ ヘキセノン環のカルボニル酸素を模倣する部分が存在しな かったことなどの複合的要因が原因である(図2). ${ }^{7)} \mathrm{ABA}$ の

A
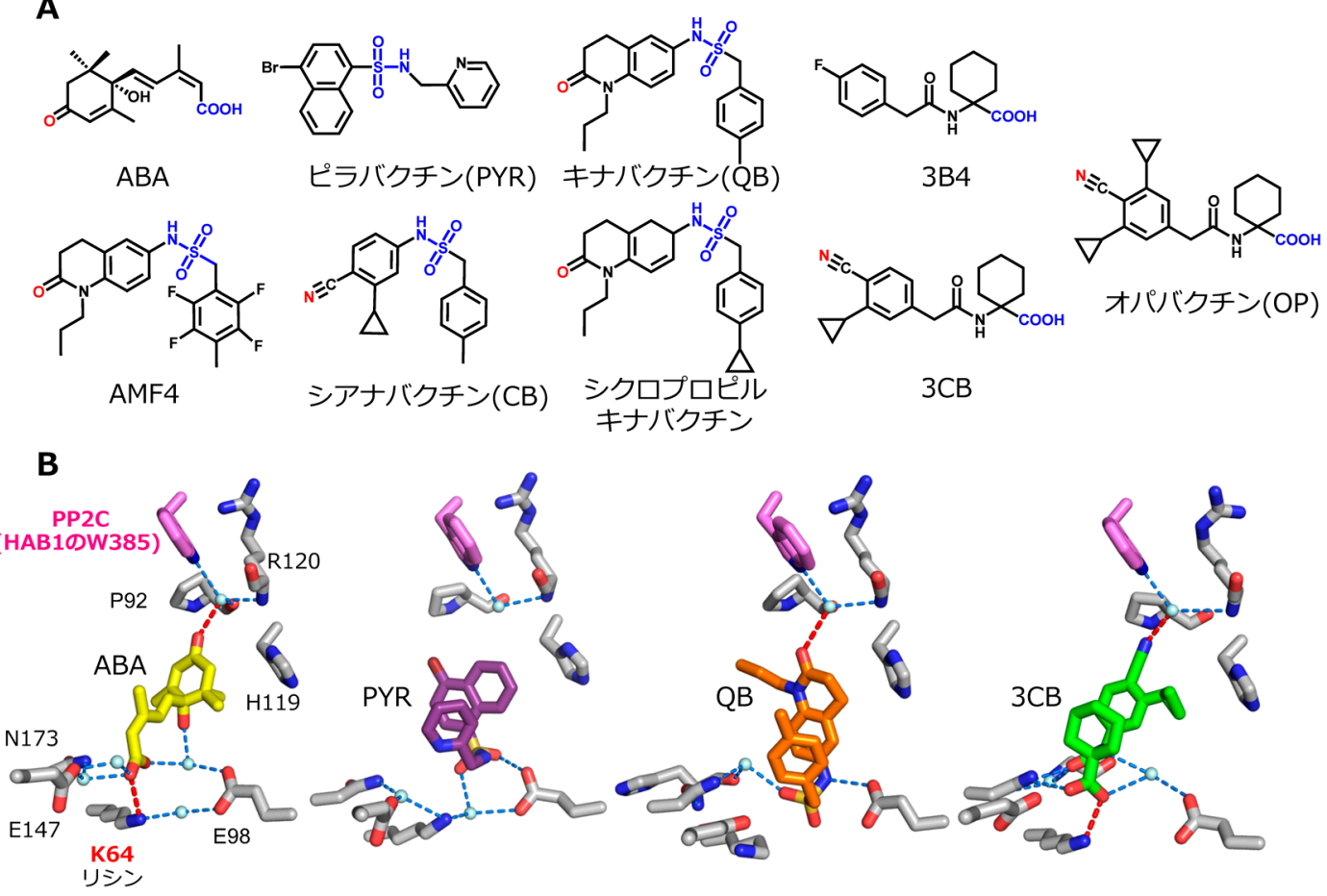

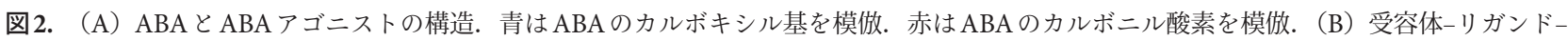
$\mathrm{PP} 2 \mathrm{C}$ （HAB1）相互作用の水素結合ネットワーク. ABA, QB, 3CB はHAB1のトリプトファン（W）残基のインドール環と水分子を介した水 素結合を形成している. ABA と $3 \mathrm{CB}$ のルボキシ基は受容体のリシン（K）残基と塩橋を形成している. 受容体のアミノ酸残基は灰色. 
A

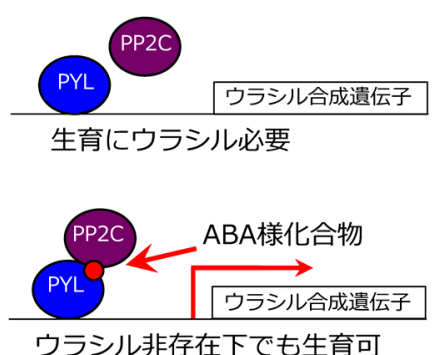

B

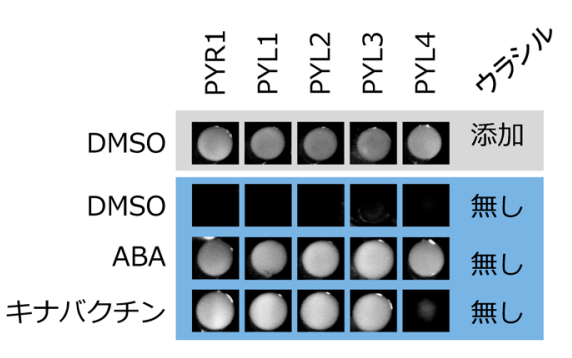

C

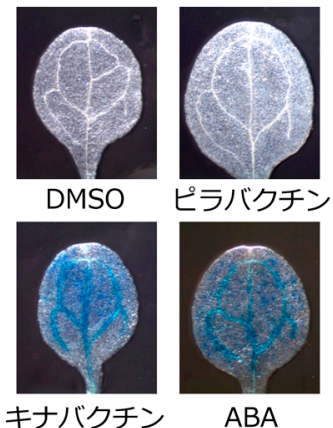

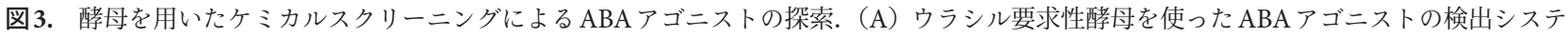
ム. ABA受容体と PP2Cが結合した場合に，ウラシル合成が起きる。（B）ABA受容体に作用する化合物が培地中に存在すれば，ウラシル非 存在下でも酵母が生育できる様子.（C）ABA応答性遺伝子（MAPKKK18）のプロモーターGUSによる植物体の ABA 応答の検出.

カルボニル酸素は，水分子を介した水素結合により受容体 とPP2Cを結びつける役割を担っており，ABAが接着分子と

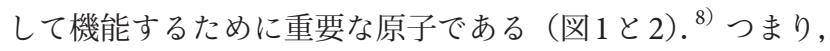
ピラバクチンの化学構造では強力な ABA応答性をもたらす ことはできないことを意味している。 そこで, 新しい化学構 造のABAアゴニストをいかにして開発するかということが 問題となるが，2010年前後には世界で様々なケミカルライ ブラリーが利用できる状況になっていた，筆者が留学してい たカリフォルニア大学リバーサイド校にも潤沢なケミカル ライブラリーが利用できたため，約6万のライブラリーをス クリーニングした。 ハイスループットなスクリーニグには, ABA 受容を簡便にモニターできる実験系を用いた，ABAが PYR/PYL受容体と標的タンパク質の PP2C の接着分子とし て機能することに着目し, 二者のタンパク質がリガンド依存 的に結合したときに $\mathrm{ABA}$ 受容を検出できる䤉母ツーハイブ リッド法（Y2H）を構築し，それを用いて新しいABAアゴ ニストをスクリーニングした（図3).ケミカルスクリーニ ングを実施していく過程で, 候補化合物が数多く単離できた が, 酵母ではよく反応するものの, 同定した化合物を植物 に投与しても活性を示さない擬陽性が多いことが判明した。 それが判明してから, $\mathrm{Y} 2 \mathrm{H}$ に加えて, シロイヌナズナの種 子発芽阻害実験と植物体の ABA応答を容易にモニター可能 な ABA 応答性遺伝子を利用したレポーターシステムを併用 しスクリーニグを継続した。 その結果, シロイヌナズナの 種子発芽阻害に加えて植物体の ABA 応答をもたらすことの できるキナバクチンの同定に成功した (図 2 と 3). ${ }^{9)}$ 生化学 解析の結果, キナバクチンはPYR/PYL受容体のうち, タイ プ3の二量体型受容体を標的にしており，ほかのタイプ1や 2 受容体は活性化せず，ピラバクチンと似たような受容体選 択的なアゴニストであった。しかし，結晶構造解析から，キ ナバクチンがもつジヒドロキノリン環の酸素原子がABAの カルボニル酸素と同様の機能を有していることが判明した (図2)。このカルボニル酸素の模倣が受容体と PP2Cを強力
に結合させることに作用していると考えられ，キナバクチン がピラバクチンよりも活性が強い理由が明らかとなった。

キナバクチンの発表以降, 数多くのキナバクチンアナログ が開発され，受容体の選択性と活性に影響する部分が明らか となった（図2）. ${ }^{10-14)}$ キナバクチンのジヒドロキノリン環を ベンゾニトリルに置換したシアナバクチンは，選択性が狭ま りPYR1 と PYL1受容体に作用するようになり，ニトリル基 は, $\mathrm{ABA}$ やナバクチンのカルボニル基と同様に, 水分子 を介した水素結合ネットワークを形成して受容体と PP2Cを 結びつける機能を持つ. ${ }^{15)}$ また, キナバクチンのベンゼン環 のメチル基をシクロプロピル基に置換したり, ベンゼン環に フッ素を導入したりすることで, 受容体との親和性を向上さ せたキナバクチンアナログが開発された. ${ }^{16,17)}$ フッ素が導入 されたAMF4はキナバクチンよりも活性が向上し, より強 い耐乾性をシロイヌナズナやダイズに対してもたらした。し かしながら，キナバクチンのアナログのいずれにおいても受 容体の選択性を広げることはできず，また単子葉植物のコム ギなどに対しては, 植物体の ABA応答をもたらすことがで きなかった，つまり，キナバクチンの基本骨格では幅広い植 物に対して生理活性を付与することや, 受容体の選択性を広 げることは困難であるということが，アナログの解析を通じ てたどり着いた結論である.

\section{3. バーチャルスクリーニングによる}

\section{ABA アゴニスト探索と構造展開}

これまで10万種類以上のケミカルライブラリーを費やし てABAアゴニストの探索が世界各国で行われ，見出された $\mathrm{ABA}$ アゴニストの基本骨格はキナバクチンのようなスルホ ンアミド型ばかりであり, 構造の多様性が芝しかった. ${ }^{18)} こ$ のような状況で, 新しい構造を有する ABAアゴニストを開 発することは容易ではない. PYR/PYL受容体と PP2Cの相 互作用を指標にして, 新たなケミカルライブラリーに対し てスクリーニグを行うことで, 最終的には新しい化学構造 
のABAアゴニストを発見できると予想できるが，ケミカル スクリーニグを行うには，相当のコストが必要である。そ こで，筆者の研究グループではこれらの問題を解決するた めに，コンピュータを用いたバーチャルスクリーニグを試み た.バーチャルスクリーニグを行う際にはPYR/PYL受容体 の立体構造の情報が欠かせないが，PYR/PYL受容体は70種 類を越える様々なタンパク質結晶構造や複合体構造が登録さ れており，豊富に蓄積した情報を活用することでスクリーニ ングが効率良く行えるはずであると推察した。コントロー ル実験において既存のABAアゴニストに対するヒットスコ アを考慮して, 最も成績の良好だった二量体型PYR1受容体 複合体 $(3 \mathrm{~K} 3 \mathrm{~K})$ と単量体型PYL10受容体複合体 (3W9R) の受容体構造を用いてバーチャルスクリーニングを行った (図 4). ${ }^{19)}$ ライブラリーは購入可能な化合物を網羅している ZINCデータベースを利用し, 1,800万化合物の情報をスク リーニングに使用した。受容体と化合物の結合を予測する ドッキング計算にはGlideを利用し，インテル ${ }^{\circledR}$ Xeon $^{\circledR}{ }^{\circledR} ロ$ セッサー CPUを搭載した凡庸PCを用いて解析を行った. ヒット化合物の上位 1 万種類まで絞り込み，その中からエナ ミン社で取り扱っている1,724個の化合物を購入した。ABA アゴニストを効率よく見つけるためにタイプの異なる PYR/ PYL受容体を混合させた受容体を用いて，リガンド依存的な PP2Cの阻害を生化学解析によって確認し，22個の化合物が 活性を有していることが明らかになった。化合物タイプは, 従来のスルホンアミドのほか, アミドやアミノプロパンジ オールを有するユニークな分子が得られ, 特に, PP2Cの活
性を最も強く阻害した3B4に注目した。

シロイヌナズナのPYR/PYL受容体を用いてPP2Cの阻害 効果を解析した結果, 3B4 はこれまでのABAアゴニストと は異なり, タイプ1受容体に作用し, タイプ2や3受容体に 対してはほとんど効果がなかった（図4と 5).この違いがど のような分子機構でもたらされているかをタイプ 3 の PYR1 受容体に3B4 をPC上で結合モデリングした（図4）。その結 果，3B4のカルボキシ基がABA と同様にPYR/PYL受容体の リガンド結合ポケットの奥側に存在するリシン残基のアンモ ニウム基と塩橋を形成し, 受容体に固定されていることが判 明した.この塩橋はこれまでスルホンアミド型の ABAアゴ ニストが形成できなかったものである（図2). 一方, PP2C と受容体の結合を安定化させるための水を介した水素結合の 形成においては, 3B4のフッ素では水分子との距離が遠く, ABAの環部のカルボニル酸素と同じ役割を担うことができ ていないと推察された。 そこで, この不良箇所を改善するた めに，これまでの ABAアゴニストの特性を再考察した. シ アナバクチンのベンゾニトリルが $\mathrm{ABA}$ のカルボニル酸素と 同じ働きをすることから，3B4のフルオロ基をニトリル基に 置換すれば, 水分子との距離も近くなり, 水素結合が可能に なることが予想された。 また，シアナバクチンのシクロプロ ピル基は受容体に対する親和性を向上させることが判明し ていた。そこで，これらの知見を統合して改良した3CBは， シロイヌナズナとコムギの全ての PYR/PYL受容体に対して 作用するパンアゴニストの活性を示した（図2と5). そし て，3CBをシロイヌナズナやコムギに投与した結果， ABA

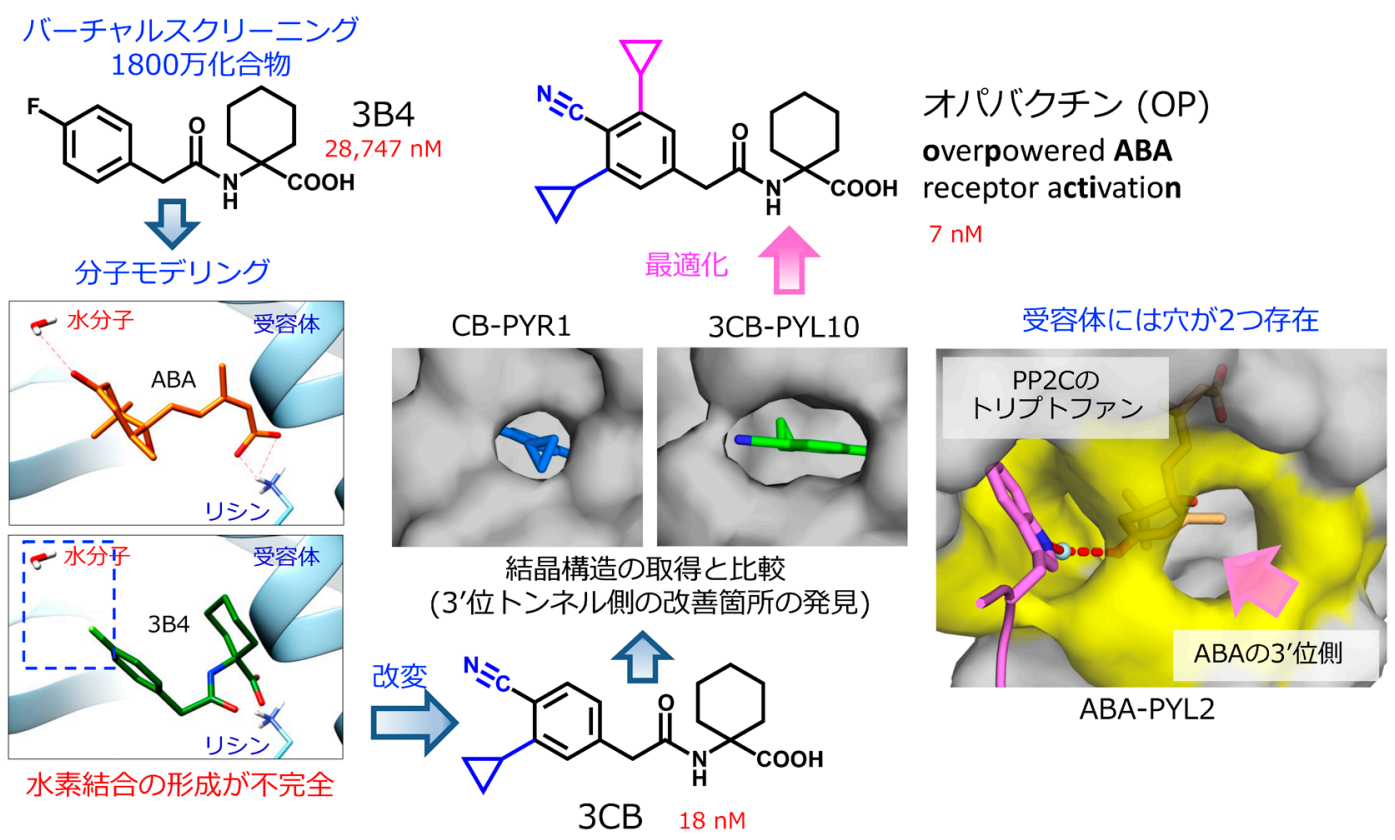

図4. バーチャルスクリーニングを利用した $\mathrm{ABA}$ アゴニストの探索と構造展開. バーチャルスクリーニングによるリード分子の発見，分子 モデリングによる不良箇所の検証，リード分子の改変，結晶構造解析による検証，再度の最適化. nM の数值はシロイヌナズナAtPYL2受容 体によるリガンド依存的な PP2C (AtHAB1 を使用) の $\mathrm{IC}_{50}$ 值（図 5参照). 
A

\begin{tabular}{|c|c|c|c|c|c|c|}
\hline & \multicolumn{5}{|c|}{ シロイヌナズナ受容体 } \\
\hline & & ABA & QB & 3B4 & ЗСB & OP \\
\hline \multirow{4}{*}{ 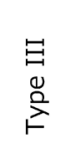 } & AtPYR 1 & 149 & 140 & $>50000$ & 48 & 13 \\
\hline & AtPYL1 & 160 & 152 & 17437 & 17 & 15 \\
\hline & AtPYL2 & 36 & 352 & 28747 & 18 & 7 \\
\hline & AtPYL3 & 12 & 1289 & $>50000$ & 14 & 7 \\
\hline \multirow{4}{*}{ 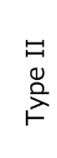 } & AtPYL4 & 27 & $>50000$ & $>50000$ & 56 & 74 \\
\hline & AtPYL5 & 7 & 301 & 517 & 6 & 8 \\
\hline & AtPYL6 & 6 & $>50000$ & $>50000$ & 20 & 32 \\
\hline & AtPYL11 & 67 & - & 3558 & 138 & 98 \\
\hline \multirow{3}{*}{ 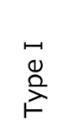 } & AtPYL8 & 57 & - & 303 & 13 & - \\
\hline & AtPYL9 & 43 & - & 584 & 49 & - \\
\hline & AtPYL10 & 148 & - & 600 & 18 & - \\
\hline
\end{tabular}

B

\begin{tabular}{|c|c|c|c|c|}
\multicolumn{5}{c}{$\sqsupset$ B ギ受容体 } \\
\hline & ABA & QB & 3CB & OP \\
\hline TaPYL1 & 128 & 196 & 23 & 7 \\
\hline TaPYL2 & 76 & 1151 & 45 & 8 \\
\hline TaPYL3 & 117 & 3941 & 84 & 15 \\
\hline TaPYL4 & 26 & $>10000$ & 12 & 16 \\
\hline TaPYL5 & 9 & 8901 & 11 & 13 \\
\hline TaPYL6 & 12 & 4553 & 7 & 6 \\
\hline TaPYL7 & 42 & $>10000$ & 20 & 18 \\
\hline TaPYL8 & 227 & - & 597 & 94 \\
\hline
\end{tabular}

C

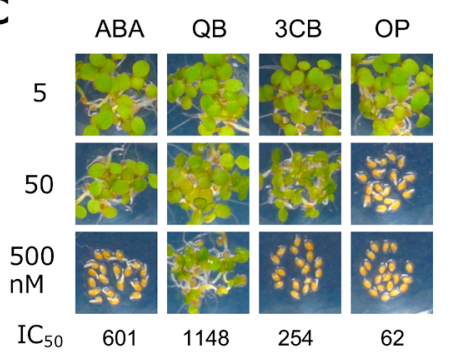

D

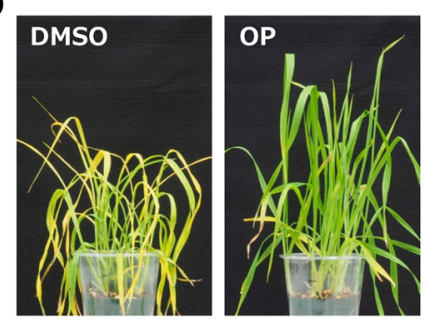

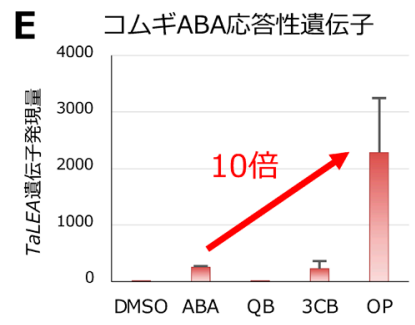

図5.バーチャルスクリーニングを利用した ABAアゴニストの探索と構造展開. (A，B） PYL受容体によるリガンド依存的な PP2C（シロイ ヌナズナはAtHAB1，コムギはTaPP2C4を使用）の IC 50 值（単位はnM).ーはPP2Cの阻害活性がないことを意味する。（C）アゴニストによ るシロイヌナズナの発芽阻害効果と $\mathrm{IC}_{50}$ 值（単位は $\mathrm{nM}$ )。（D）コムギ乾燥ストレス処理における $\mathrm{OP}$ の効果．（E）受容体アゴニストによるコ ムギABA 応答性遺伝子T TaLEA の発現誘導.

と同等かあるいは $\mathrm{ABA}$ を超える活性を示した（図5).こう して完成させた $3 C B$ が想定通りに受容体に結合しているか を，タンパク質結晶構造を取得して解析してみると，予想に 反して，3CBのシクロプロピル基は親和性を高めるための 受容体表面の3'位トンネル側に配置されておらず，受容体 のポケット奥側で固定化されていた（図4)。そこで，3'位 トンネル内のアミノ酸残基との相互作用を狙って $3 \mathrm{CB} に シ$ クロプロピル基をもう一つ追加した分子を合成し，オパバ クチンと名付けた. その結果, 想定通りに, オパバクチン は $3 \mathrm{CB} よ り も \mathrm{PP} 2 \mathrm{C}$ に対する $\mathrm{IC}_{50}$ 值が低くなり, タイプ3受 容体に対してはABAを超える活性を有することが明らかと なった（図5)。また，オパバクチンはコムギの受容体に対 してはパンアゴニストとして機能したが，シロイヌナズナに おいてはタイプ1受容体に対する活性が消失した。この理由 は，オパバクチンに追加されたシクロプロピル基が受容体タ イプ1間で保存されている3'位トンネル内のロイシン残基に よって立体障害を受けたためである。このようにして完成さ せたオパバクチンを実際に植物に投与した結果, シロイヌナ ズナ種子発芽阻害活性やコムギの ABA 応答性遺伝子発現誘 導はABA と比べても10倍程度高い活性を示した（図5)。興 味深いことに，シロイヌナズナのタイプ3受容体を欠損する 変異株では, オパバクチンの種子発芽阻害効果や気孔閉鎖に よる葉の温度上昇が消失したことから，オパバクチンの強い $\mathrm{ABA}$ 生理活性は低親和性のタイプ3受容体を介して行われ
ていると考えられる. 受容体タンパク質の立体構造を利用し たバーチャルスクリーニングにより発見した分子を，これま で得た多数のアゴニストの分子構造や受容体タンパク質との 複合結晶構造の情報を活用することで, 理論的に分子を最適 化させることに成功した。

\section{おわりに}

多くの植物ホルモン受容体の構造が明らかにされているこ とから ${ }^{20)}$ 今回紹介したバーチャルスクリーニングの手法を 用いることで, 植物ホルモンアゴニストの開発が効率化する と思われる. しかし, 基礎研究において活躍した人工化合物 を実用化させるには安全性, 生産コスト, そして市場の二ー ズなどクリアすべき問題が多々残っている，一方で，今回は ABAアゴニストの開発について紹介したが，ABA以外にも 植物の環境ストレス耐性の向上に酶酸, エタノール, GABA なども関わることが報告されている. 気候変動に伴う環境入 トレスによる農作物への被害は年々大きくなっており，その 被害を緩和するためのバイオシュティミュラントの市場が世 界で拡大してきている．特に，バイオシュティミュラントが どのようにして植物の環境ストレス耐性を向上させるかとい う分子機構は不明な点が多い。これまで基礎研究で特定・発 見されたストレスに関連した低分子有機化合物や遺伝子郡と バイオシュティミュラントの効果が紐付けされることで, 農 作物生産において, 効果的に環境ストレスを緩和し, 生産性 
を上げる技術が創出できるのではないかと思っている.

\section{引用 文 献}

1) R. Mega, F. Abe, J. K. Kim, Y. Tsuboi, K. Tanaka, H. Kobayashi, Y. Sakata, K. Hanada, H. Tsujimoto, J. Kikuchi, S. R. Cutler and M. Okamoto: Nat. Plants 5, 153-159 (2019).

2) 秃 泰雄：ミヨビ農法, 農山漁村文化協会, 2011.

3) S. R. Cutler, P. L. Rodriguez, R. R. Finkelstein and S. R. Abrams: Annu. Rev. Plant Biol. 61, 651-679 (2010).

4) F. Hauser, R. Waadt and J. I. Schroeder: Curr. Biol. 21, 346-355 (2011).

5) F. Dupeux, J. Santiago, K. Betz, J. Twycross, S. Y. Park, L. Rodriguez, M. Gonzalez-Guzman, M. R. Jensen, N. Krasnogor, M. Blackledge, M. Holdsworth, S. R. Cutler, P. L. Rodriguez and J. A. Márquez: EMBO J. 30, 4171-4184 (2011).

6) S. Y. Park, P. Fung, N. Nishimura, D. R. Jensen, H. Fujii, Y. Zhao, S. Lumba, J. Santiago, A. Rodrigues, T. F. Chow, S. E. Alfred, D. Bonetta, R. Finkelstein, N. J. Provart, D. Desveaux, P. L. Rodriguez, P. McCourt, J. K. Zhu, J. I. Schroeder, B. F. Volkman and S. R. Cutler: Science 324, 1068-1071 (2009).

7) K. Melcher, Y. Xu, L. M. Ng, X. E. Zhou, F. F. Soon, V. Chinnusamy, K. M. Suino-Powell, A. Kovach, F. S. Tham, S. R. Cutler, J. Li, E. L. Yong, J. K. Zhu and H. E. Xu: Nat. Struct. Mol. Biol. 17, 1102-1108 (2010)

8) K. Melcher, L. M. Ng, X. E. Zhou, F. F. Soon, Y. Xu, K. M. SuinoPowell, S. Y. Park, J. J. Weiner, H. Fujii, V. Chinnusamy, A. Kovach, J. Li, Y. Wang, J. Li, F. C. Peterson, D. R. Jensen, E. L. Yong, B. F. Volkman, S. R. Cutler, J. K. Zhu and H. E. Xu: Nature 462, 602-608 (2009).

9) M. Okamoto, F. C. Peterson, A. Defries, S. Y. Park, A. Endo, E. Nambara, B. F. Volkman and S. R. Cutler: Proc. Natl. Acad. Sci. U.S.A. 110, 12132-12137 (2013).

10) S. R. Cutler and M. Okamoto: US9345245 (2016).

11) S. R. Cutler, S. V. Wendeborn, P. J. Jung, M. D. Lachia and R. Dumeurier: US Patent App.14/899,089 (2016).

12) J. Frackenpohl, G. Bojack, H. Helmke, S. Lehr, T. Müller, L. Willms, H. Dietrich, D. Schmutzler, R. Baltz and U. Bickers: US Patent 20170027172 (2017).

13) J. Frackenpohl, G. Bojack, H. Helmke, L. Willms, S. Lehr, T. Mül- ler, H. Dietrich, D. Schmutzler, R. Baltz and U. Bickers: US Patent 20180020662 (2018).

14) M. D. Lachia, S. V. Wendeborn, P. J. M. Jung, D. Sabbadin, O. Loiseleur and A. Beck: US Patent 20180044297 (2018).

15) A. S. Vaidya, F. C. Peterson, D. Yarmolinsky, E. Merilo, I. Verstraeten, S. Y. Park, D. Elzinga, A. Kaundal, J. Helander, J. Lozano-Juste, M. Otani, K. Wu, D. R. Jensen, H. Kollist, B. F. Volkman and S. R. Cutler: ACS Chem. Biol. 12, 2842-2848 (2017).

16) D. Elzinga, E. Sternburg, D. Sabbadin, M. Bartsch, S. Y. Park, A. Vaidya, A. Mosquna, A. Kaundal, S. Wendeborn, M. Lachia, F. V. Karginov and S. R. Cutler: ACS Chem. Biol. 14, 332-336 (2019).

17) M. J. Cao, Y. L. Zhang, X. Liu, H. Huang, X. E. Zhou, W. L. Wang, A. Zeng, C. Z. Zhao, T. Si, J. Du, W. W. Wu, F. X. Wang, H. E. Xu and J. K. Zhu: Nat. Commun. 8, e1183 (2017).

18) W. Dejonghe, M. Okamoto and S. R. Cutler: Plant Cell Physiol. 59, 1490-1499 (2018).

19) A. S. Vaidya, J. D. M. Helander, F. C. Peterson, D. Elzinga, W. Dejonghe, A. Kaundal, S. Y. Park, Z. Xing, R. Mega, J. Takeuchi, B. Khanderahoo, S. Bishay, B. F. Volkman, Y. Todoroki, M. Okamoto and S. R. Cutler: Science 366, eaaw8848 (2019).

20) J. Takeuchi, K. Fukui, Y. Seto, Y. Takaoka and M. Okamoto: Plant J. 105, 290-306 (2021).

\section{略 歴}

岡本昌憲（おかもと まさのり）

生年月日：1977年9月 27 日

最終学歴：東京都立大学大学院理学研究科博士課程

研究テーマまたは主な職歴：植物ホルモンのアブシシン酸の 代謝制御機構とシグナル伝達の解明. 植物ホルモ ンに関連したケミカルバイオロジー。2005年4月 日本学術振興会特別研究員 (DC2)，2007年4月理 化学研究所基礎科学特別研究員, 2010年4月日本 学術振興会特別研究員 (PD), 2011年10月日本学 術振興会海外特別研究員, 2013年3月鳥取大学乾 燥地研究センター助教, 2017年4月宇都宮大学バイ オサイエンス教育研究センター助教，2019年7月同 准教授 $(2015$ 年 12 月-2019年 3 月科学技術振興機 構さきがけ研究員).

趣味：アクアリウム。 日本茶や日本酒. 実験. 